$y_{\text {LA-6095-MS }}$

Informal Report

UC. $79 b$

Repoiting Date: September 1975

Issued: October 1975

\title{
The Consequences of Sodium Bond Loss from an LMFBR Carbide Fuel Element
}

by

Jerry F. Kerrisk

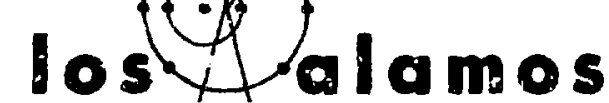

sciemitio laboratory

of the University of California

los alAMOS, NEW MEXICO 87545

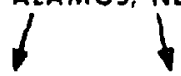

An Affirmative Action / Equal Oppartunity Employer 
In the interest of prompt distribution, this report was not edited by the Technical Information staff.

This work was supported by the U. S. Energy Research and Development Administration, Division of Reactor Research and Development.

Printed in the United Stoim of America. Available trom National Technical Information Service

U S Department of Commerce

S285 Port Royal Road

Springtield, VA 22151

Price: Prinled Copy SA.0\% Mieroliche $\$ 2.25$

This repon way prequered wo an account of worh nponeored

be the Uaited Sinter Governmeat. Neither the United Stated

nor the United Stales Everng Revesrch and Development Ad-

ministration, nor any of their ens ploy.ses, nor eny of thetr con-

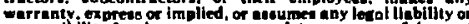

retponibility for the cocuracy. completenesc, of unetulpene of

any Intormation. epvaratus, produci, or process discloved, or

reprewerts.
rifhes. 
THE CONSEQUENCES OF SODIUM BOND

LOSS FROM AN LMFBR CARBIDE FUEL ELEMENT

by

Jerry F. Kerrisk

\begin{abstract}
The consequences of sodium bond loss from a uranilu-plutonium carbide fuel element during normal eteady state operation have been assessed. The elements considered are typlcal of those currently being irradiated in EBR-II, and Include elomente with and without shroud tubes. The analysis presented is very conservative in that the many simplifylng assumptions regulred were made to predlct worse consequences than would be found in a reallstic angiysis. Following sodium bond loss, fuel melting occurs, but the fuel rapidy resolidifles after slumping out to contact the clad. Even if molten fuel were lost through an exdsting clad fallure, the maximum fuel temperatures attalned are below those requirod to initiate a vapor explosion in the sodium coolant. The small amount of mclten fuel that might escape through an exdsting clad fallure would have little or no effect on adjacent elements.
\end{abstract}

1.

\section{DNTAODUCTION}

The uranium-plutonium carbide fuel system is a primary candidate for use as an advanced fuel in liquid metal fast breeder roactors. Thle fuel system offers significant advantages over uranium-plutonium oxdde in reactor doubling time and breeding ratio, mainly due to the bgher: fiselle atom denaity in the carblde fuel. There are two fuel element designs belng actively studied ue:? $(\mathrm{U}, \mathrm{Pu}) \mathrm{C}$ fuel. 1,2 A hellum-bonded fuel element useB hellum gas as the thermal bond between the fuel and the metallic (usually stainless steel) clad tubing. The Initial fuel-clad diametral gep lo small (usually less than $0.3 \mathrm{~mm}$ ) so that fuel-clad mechanical interaction occurs during Ir radlation due to fual sweliing. Fuel centerline temperatures are in the range of $1400-2000^{\circ} \mathrm{C}$ initially, but drop during Irradlation as the fuel-clad gap closes and better thermal contact is obtained. A sodium-bonder fuel element uses liquld sodium as the thermal bond between the fuel and clad. The inltial fuel-clad dametral gap is norinally in the renge of 0.4 to $0.8 \mathrm{~mm}$; thls is large enough to allow fual ewelling without fuel-clad contact during the llfe of the element. The large gap is possible since the high thermal conchictivity of liquid sodum results in very small temperature drops through the gap region. Fuel centerline temperatures are normally less than $1200^{\circ} \mathrm{C}$.

A potentlal safety problem with Bodium-bonriv! fuel elements is the behavior of the element following a loss of the sodlum bond. The most probable cause of sodium bond loss is a clad fallure below the sodium level In the element which allows the bond sodium to be lost to the coolant. At beginning of life, the preseure in the element plenum above the bond sodium will only be slightly higher than the coolant pressure. However, as 
Irradlation proceeds, fisslon gas will be released from the fuel 80 that end of life pressires in the element plenum can be much greater than those in the coolant. Thus throughout the fuel element life a driving force exdsts for sodium bond loss to the coolant. Following bond loss, the liquid sodium will be replaced by plenum gas. At the beginning of life this is pure hellum; by the end of life the plenum gas ls mostly fleston gas (xenon and krypton), which bas a much lower thermal conductivity than hellum. The change from liquid sodium to plenum gas in the bond recuces the thermal conductance of the bond by about an order of magnitude; thus, high fuel temperatures and Hkely fuel melting will follow loss of sodium bond.

An added complication 1 . vonsldering the loss of the sodium bond is the presence of fuel fragment restraints or shroud tubes in elemente. ${ }^{2,3}$ Shroud tubes are perforated thln wall (less than $0.1 \mathrm{~mm}$ ) tubes which fit around the fuel with a small diametral gap (epproximately $0.05 \mathrm{~mm}$ ). The shroud tubes are deslgned to prevent fuel fragments from cracked fuel zellets from rearranging inside the clad. Fuel fragment rearrangment and mechanical interantion with the clad during irradiation can lead to localized clad stresees. Some fatlures In sodium-bonded elements have been attributed to thlg phenomenon. Shroud tubes with a high melting point (tantalum) and with a low melting point (316 stainless steel) have been used. ${ }^{3}$

The object of this report is to as8ese the consequences of a lose of sodium bond from a carblde fueled element during rermal steady state operatjon. The complexdty of the Initial fuel alement state (for example, Its burnup, flesion gas release, fuel crackng pattern, gap size, and linear power) and the further complexity of the phenomena following bond loss preclucia a reallatlc analysis of this accident. Thus the analyeis here 18 meant as a conservative or îlmlting assesement of bond lose, and Is not representative of what would actually happen. Many simpilfying assumptions were made throughout the analysis; these aseumptions were conservative in the sense that they tend to predict worse consequences than would result from a realistic analysis.
Even with the earies of conservative assumptions made, the consequences of sodium bond loss are far from cata8trophlc. Fual melting can occur, but the fuel will rosolidify on contact with the clad. Loss of sodium bond from a fuel element would have little or no effect on adjacent elernents.

Section 2 of the report describes the nomlnal fuel element parameters and the steady state operating condltions of the fuel elements being arialyzed. Section $3 \mathrm{dls}-$ cusses the consequences of a loss of bond through a clad failure during normal operation. Tals eection lo divided Into discussions of a model used to, calculate fuel and clad temperatures following bond loss and a presentation of the maxdmum fuel and clad temperatures calculated. Sectlon 4 presents a calculation of the sodium coolant temperatures resulting from interestion with molten fuel that might escape from the elemer.t. Both instantaneous molten fuel-coolant Interface temperatures and bulk coolant heating are coneldered. Section 5 contalns a discusslon of the overall aralysla.

\section{ELEMENT IESIGN AND NORMAL OPERATING CONDITIONS}

The fuel elaments congldered here are based on the design of the "Soriee U5100 Slngly Clad Carblde Experiments" which are being Irrarliated in EBR- ${ }^{3}{ }^{3}$ Each fuel element contains uranium-plutonium carblde fuel pellets enclissed in a metallic clad tube which is

$$
\begin{aligned}
& 7.14 \mathrm{~mm}(0.281 \mathrm{ln}) 1 . \mathrm{d} \text {. by } \\
& 7.87 \mathrm{~mm}(0.310 \mathrm{ln}) 0 . \mathrm{d} \text {. }
\end{aligned}
$$

Some elemente, have shroud tubes. Each element is wire wrapped for crolant flow spacing in the subassembly. Table I llete \&. description of the fuel elements along with nominal operiting conditions of each slement. The llnear power and futil element temperathires were calculated ueing the PISTEMP code. 4 For the calculation, the Bubassembly (11) fuel elements and 1 dummy element) was assumed to be in core lucation $4 B I$ In EBR-II, with a total sodlum. flow of $45,20 \mathrm{~cm}^{3} / \mathrm{s}(78 \mathrm{gpm})$. The nominal Iiselon rateis for this location were recuced by $9 \%$ to compensate for the latest eatimates of actual EBR-II fleston rates at $62.5 \mathrm{~mW}$. The mardmum goa! burnup of these elemente lo 12 at. $\%$. 
TABLE I

U5100 SERIES ELEMENT PARAMETERS AND OPERATING CONDITIONS

\begin{tabular}{|c|c|c|c|c|c|c|c|c|c|}
\hline $\begin{array}{l}\text { Element } \\
\text { Number }\end{array}$ & $\begin{array}{l}\text { Fuel }^{8} \\
\text { Type }\end{array}$ & $\begin{array}{l}\text { Fuel }^{b} \\
\text { Bensity } \\
\text { ofhoo: }\end{array}$ & $\begin{array}{l}\text { Diametral } \\
\text { Gas, mm }\end{array}$ & $\underline{\text { Shroud }}^{\mathrm{d}}$ & Clad $^{\mathrm{e}}$ & $\begin{array}{l}\text { Peak Linear } \\
\text { Power, } \mathrm{kW} / \mathrm{m}\end{array}$ & $\begin{array}{l}\text { Peak Fuel } \\
\text { Temp. }{ }^{\circ} \mathrm{C}\end{array}$ & $\begin{array}{l}\text { Peak Clad } \\
\text { Temp. }{ }^{\circ} \mathrm{C} \\
\end{array}$ & $\begin{array}{l}\text { Outlet }^{f} \\
\text { Na Coolant } \\
\text { Temp. }{ }^{\circ} \mathrm{C} \\
\end{array}$ \\
\hline U24 1 & MC & 94 & 0.46 & None & 304 SS & 107 & 1035 & 565 & 466 \\
\hline U242 & $\mathrm{MC}$ & 93 & 0.44 & None & 304 SS & 107 & 1040 & 576 & 477 \\
\hline U243 & $\mathrm{MC}$ & 93 & 0.80 & None & 304 SS & 103 & 1030 & 559 & 463 \\
\hline U244 & MC & 93 & 0.44 & None & 304 SS & 107 & 1035 & 565 & 466 \\
\hline U245 & $\mathrm{MC}$ & 93 & 0.81 & None & 304 SS & 103 & 1033 & 569 & 473 \\
\hline U246 & MC & 93 & 0.43 & None & 316 SS & 110 & 1058 & 581 & 480 \\
\hline U247 & MC & 93 & 0.81 & None & $316 \mathrm{SS}$ & 103 & 1027 & 558 & 463 \\
\hline U248 & MC & 93 & 0.81 & None & 316 SS & 101 & 1022 & 565 & 471 \\
\hline U249 & MC & 93 & 0.43 & None & INC-800 & 109 & 1057 & 581 & 479 \\
\hline U250 & MC & 93 & 0.81 & Norí & INC-800 & 101 & 1055 & 628 & 536 \\
\hline U251 & $\mathrm{MC}$ & 93 & 0.81 & None & 304 SS & 101 & 1056 & 629 & 537 \\
\hline U252 & MC & 93 & 0.64 & $\mathbf{v}$ & 304 SS & 101 & 1028 & 566 & 471 \\
\hline U253 & MC & 93 & 0.66 & $\mathrm{Fe}$ & 304 SS & 99 & 1046 & 624 & 533 \\
\hline U254 & MC & 93 & 0.66 & 304 SS & 304 SS & 99 & 1045 & 623 & 593 \\
\hline U256 & $\mathrm{MC}+15 \% \mathrm{M}_{2} \mathrm{C}_{3}$ & 96 & 0.61 & v & 304 SS & 102 & 1017 & 557 & 462 \\
\hline U257 & $\mathrm{MC}+15 \% \mathrm{M}_{2} \mathrm{C}_{3}$ & 96 & 0.58 & $\mathrm{Ta}$ & INC-800 & 101 & 1048 & 629 & $\mathbf{5 3 7}$ \\
\hline ป258 & $\mathrm{MC}+15 \% \mathrm{M}_{2} \mathrm{C}_{3}$ & 96 & 0.58 & 304 SS & 304 SS & 101 & 1048 & $\hat{6} 29$ & $\mathbf{5 3 7}$ \\
\hline U259 & $\mathrm{MC}+15 \% \mathrm{M}_{2} \mathrm{C}_{3}$ & 96 & 0.58 & 304 85 & INC-800 & 103 & 1020 & 558 & 463 \\
\hline
\end{tabular}

a. $M=\left(\mathrm{U} .{ }_{35} \mathrm{Pu} .15\right)$

b. Theoretical Density of $M C=13.45 \mathrm{~g} / \mathrm{cm}^{3}$; Theoretical Density of $\mathrm{M}_{2} \mathrm{C}_{3}=12.72 \mathrm{~g} / \mathrm{cm}^{3}$.

c. The shroud thickness is not included in the diametral gap thickness.

d. Shroud tubes are $0.08 \mathrm{mn}$ thick tubes with slots over $25 \%$ of the tube area.

e. All clad material is solution annealed.

f. The inlet $\mathrm{Na}$ temperature was aseumed to be $371^{\circ} \mathrm{C}$ 
The fisston gas content of the plenum gas and the total plenum pressure which would result during steady state Irradiation were calculated for these elementa for a number of assumed fission gas releases. For a plenurs volume of $15 \mathrm{~cm}^{9}$ there were $6 \times 10^{-1}$ moles of hellum in the plesum at fabrlcation (atmospheric pressure and $25^{\circ} \mathrm{C}$ ). At 12 at. \% burnup, $1.5 \times 10^{-2}$ moles of fission gas ( $\mathrm{Kr}+\mathrm{Xe}$ ) wll be generated. Assuming a linear generation and release rate with burnup, the totel plenum prasisure and Ite compositton can be calcultited. Table II showg the results of this calculation. The helium content of the plenum gas will be used to estimate the thermal conductivity of the gas which replaces the sodium bond following bond loss. The total pleaum pressure will be used to estimate the possible rate of nolten fuel losg through a clad fallure following bond loss.

The fuel-clad gap thickmeas will vary during steady state irradlation che to clad swelling and fuel swelling. Clad swelling was egtimated for the fuel element conditlons in EBR-II. Clad temperatures were taken from the steacty state calculations using PINTEMP. Clad fluences were estimated using $7.2 \times 10^{21} \mathrm{n} / \mathrm{cm}^{2}$ (>0.1 Mev) per at. \% burnup (peak) at the core midplane, and $5.6 \times 10^{21}$ $\mathrm{n} / \mathrm{cm}^{2}$ (>0.1 Mev) per at.\% buxnup (peak) at the top of the core. Table III lists the range of clad swelling calculated for the elemente in the subassembly as a function of burnup. The wide range results from the variation of clad material, fluence, and temperature throughout the subassembly. Fuel swelling was assumed to be a constant 3 vol\% per at.\% buxnup. Using the clad swelling and fuel swelling estimates, the gap thickmess can be calculated as a function of burnup. Initial gap thickness (at room temperature) ranged from $0.43 \mathrm{~mm}$ to $0.81 \mathrm{~mm}$ (see Table I). Table UI also llsts the maxdmum gap thickness calculated for elements with initial gaps of $0.43 \mathrm{~mm}$ and $0.81 \mathrm{~mm}$. The maximum gap resulte from aesuming the maxdmum clad swelling. Even using the maximum clad swelling rate, the fuel swelle faster than the clad. Thus the gape get smaller as irradiation proceeds.
TABLE II

U5100 ETEMENT PLENUM PRESSURE AND HELIUM CONTENT OF PLENUM GAS

\begin{tabular}{|c|c|c|c|}
\hline $\begin{array}{l}\text { \% Fission } \\
\text { Cas Reloage }\end{array}$ & $\begin{array}{l}\text { Atom o } \\
\text { Burnup }\end{array}$ & $\begin{array}{c}\text { Plenum } \\
\text { Pressurg, atm }\end{array}$ & $\begin{array}{l}\text { O Helium is } \\
\text { Plonune Cins }\end{array}$ \\
\hline \multirow[t]{5}{*}{20} & 0 & 2.5 & 100 \\
\hline & 9 & 6.4 & 45 \\
\hline & 6 & 10.0 & 28 \\
\hline & 9 & 13.5 & 21 \\
\hline & 12 & 17.0 & 16 \\
\hline \multirow[t]{5}{*}{30} & 0 & 2.5 & 100 \\
\hline & 9 & B. 0 & 36 \\
\hline & 6 & 13.3 & 21 \\
\hline & $\mathbf{9}$ & 18.5 & 15 \\
\hline & 12 & 23.7 & 12 \\
\hline \multirow[t]{5}{*}{50} & 0 & 2.5 & 100 \\
\hline & 3 & 11,5 & 24 \\
\hline & 6 & 20.3 & 14 \\
\hline & 9 & 29.0 & 10 \\
\hline & 12 & 37.9 & 7 \\
\hline
\end{tabular}

\footnotetext{
The remalnder of the plenum gas is flesion gas $(15$ Q $K r$ and $85 \%$ Xe)
}

TABLE III

\section{CLAD SWELLING AND GA O SIZE}

\begin{tabular}{|c|c|c|c|}
\hline \multirow{2}{*}{$\begin{array}{c}\text { Burnup } \\
\text { at. } \% \\
\end{array}$} & \multirow{2}{*}{$\begin{array}{c}\text { Clad } \\
\text { Volumetric } \\
\text { Swelling, \% }\end{array}$} & \multicolumn{2}{|c|}{ Maximum Gap } \\
\hline & & $\mathrm{mm}$ & $\underline{m m}$ \\
\hline o & 0 & 0.43 & 0.81 \\
\hline 3 & $0-0.2$ & 0.23 & 0.82 \\
\hline 6 & $0-1.7$ & 0.08 & 0.48 \\
\hline 9 & $0.1-5.6$ & 0.0 & 0.38 \\
\hline 12 & $0.2-12.0$ & (Q) & 0.34 \\
\hline
\end{tabular}

Maxdmum burnup of small gap elements limited to 8 at. $\%$. 


\section{¿. LOSS OF BOND DURING NORMAL OPERATION \\ 3.1 Cenerw Consideratlong}

The causis of sodlum bond loss considered is a clad defect which allows the bond sodium w be lost from the clement into the coolant. The release would cause an Increase in fission product activity in the coolant, and is thus dotectable. The sequence of events involved lo:

a. a clad defect accurring below the top of the fuel column,

b. the loss of the exdlum bond through the defect into the coolant.

c. gas blanketing of the fuel by plenum gas which reriuces the thermal contuctance oi the bond,

d. fuol (and shroud) molting if the linear power is high enough and the gap large enough.

e. slumping of the molten fuel (and shroud) against the clad which inireases the thermal ccoductance of the bond, and

f. resolidifleation of the molten metertal. Causes for concern during thls sequence are posstble clad melting from contact with the molten fuel, and the posetblo flow of molten fuel out the cledding defect into contact with the coolant bodium where a molter: fuel coolant intoraction (MFCI) can occur.

The likellhood of clad meiting from contact wh this molten fuel can be estlmated from calculations of the clad suxface temperature following contact with the moiten

fuel. Experimental evidence is also avallable from IrractIation tests where molten fuel did contact oladding. The likelihood oi a sevare MFCI ls mainly determined by the mndmum fuel temporaturos attained. If the molten fuel is hot enough to ralse the godium coolent temperature above ite homogenecue nucleation temperatury, then a vapor explosion is posgible.

In the U5100 Serles there are throe groups of elements which could boheve difierently following a loas of bond:

a. the unshrouded elements, U2A1 through U251,

b. the elemente ohrouded with otalnleses oteol, iron or vanadium, U252, U253, U254, U256, U258, and U259, and

c. the element shrouded with tantalum, U25?.
This grouping is based on the presence or absenco of a shroud tube and the melting polmt of the shroud tube. In the unshrutuded elements there is nothlng to restrict the slumplng of the molten fuel out to the clad. In the ele ments sbrouded with stalnless steel $\left(1425^{\circ} \mathrm{C}\right.$ melting point). Iron $\left(1540^{\circ} \mathrm{C}\right.$ melting polnt), and vanadium $\left(1390^{\circ} \mathrm{C}\right.$ meltIng polnt) the ehroud material will melt before the fuel is completely molten $\left(2440^{\circ} \mathrm{C}\right.$ llquidus temperature $)$. Thus the molten fuel and shroud can slump out to the cled. In the element shrouded with tantalum $\left(2995^{\circ} \mathrm{C}\right.$ melting point) the shroud fill uot be molten when the fuei starts to slump. Thus, the fuel will be forced to slump through the shroud tube slote to contact the clad.

The remainder of this section describes the models used to calculate the maximum fuel tempersicures attolned following a lose of bond, and the maximum clad temperaaires attained following contact with molien fuel. The results for a variety of conditions are presented.

\subsection{Feat Trangior Calculational Model}

Heat transfar calculations wero performed for threes model elements:

a. en unshrouded element with $0.83 \mathrm{mir}$ (33 mil) diametral gap between the fuel and clad I.d.,

b. an element with 304 stoinless steal shroud and a $0.53 \mathrm{~mm}$ (21 mll) diametral gap between the ohroud o.d. and clud 1.d., and

c. an elemons with tantalum shroud and a 0.53 mm (21 mill dlanotral gap between the shroud o.d. and clad I.d.

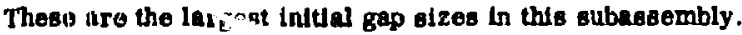
Calculations were performed using initial gap olzes as a conservatlve assumption alnce these are the largest geps during the life of the element. The element with the otalnlens oteri ohroud is aleo meant to cover the elemento wth iron and varadium alurouds. Although the properties of venedium are gomewhat different than otainless ateel, the outceime of the calculation ls very inseneitive to the shroud piroperties as long as the sbroud has molted when the fuel hes staried to olump.

The calculations were one dimenalonal (radial) and esoumed concentric fual, shroud, and clad. The neglect of exdal contuction and of the possibility of liquid sodium 
remaining around the clrcumference of the bond is conservative in that it wlll pred"ct higher fuel temperatures than if these othor conduction paths were consldered. The effect of pellet eccentrlcity was estimated by performing an approxdmate steidy state calculation of the maximum fuel temporatures as a funciton of relative eccentricity (the ratio of pallet offeet to $t /$ radial gap when concentric). A gas bond was assumed. Figuro 1 shows the ratlo of madmum fuel temporature with an eccentric pellet $w$ the maxdmum for a concentric pellet. plc tted as a function of relative eccentriclty. It is ovident that any eccentricity sends to rectuce the maximun, fuel tomperature so that a concentric calculation to conservattre.

The numarlcal heat transfer calculations whlch determlned the maximum fuel temperatures and maxd mum clad temperatures used the CINDA code. 6 The node layout for the shrouded and unshrouded elements ls shown in Fig. 2. The cold thmensions used were $\mathrm{R}_{f}=3.25 \mathrm{~mm}$, $\mathrm{R}_{\mathrm{Sl}}=2213 \mathrm{~mm}, \mathrm{R}_{\mathrm{BC}}=3.302 \mathrm{~mm}, \mathrm{R}_{\mathrm{cl}}=3.5687 \mathrm{~mm}$, and $R_{c o}=3.937 \mathrm{~mm}$. The muterial propertles are listed in Appendix A. The heat transfer coefficlent to the flowing sodium coolant was assumed constant at $205 \mathrm{~kW} / \mathrm{m}^{2}{ }^{\circ} \mathrm{C}$.

The heat transfer calculationo start at an Initual steady state temperabure diatributlon with the sodium bond Intact. At zero tlmo the gep oo irim is completely replaced by plenum gas and a translent calculation follows the element temperatures. This is a conservative model since any : iquild sodlum rempining aroand the gap would provldo a high conductance path to the clad and thus roduce the maxmum fuol temperatures. The plenum gas vas assumed to be 10 , hellum--90\% flsston ges. Thls emounts to an end of life (loweat thermal conductivity') cor rosition with a $40 \%$ fission gas releage. Both conducIICn and radlation were allowed acrogs the gas regions, The fuel, shroud, and clad radil were corrected for ti. -mal expansion in the steady state calculation end throughout the transient calculation. For the fuel thermal axpenston calculation the fuel was asumed to be a bolld pellet. The actual fuel with radinl cracke will have a greater expansion. If fuel-shroud contact occurred while the fuel and shroud were etill solld, the shroud was assumed to

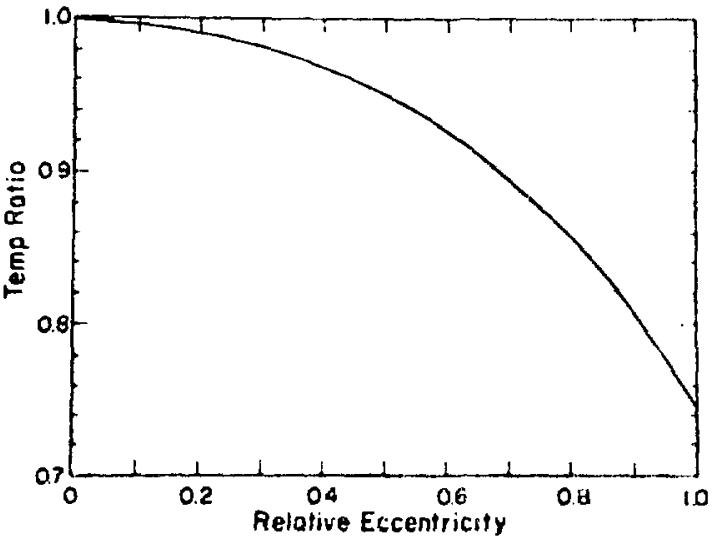

Fig. 1. Ratio of madimum fuel temp. cure with an eccentrle pellat to the maximum for a concentric pellet as a function of relativo eccentricity.

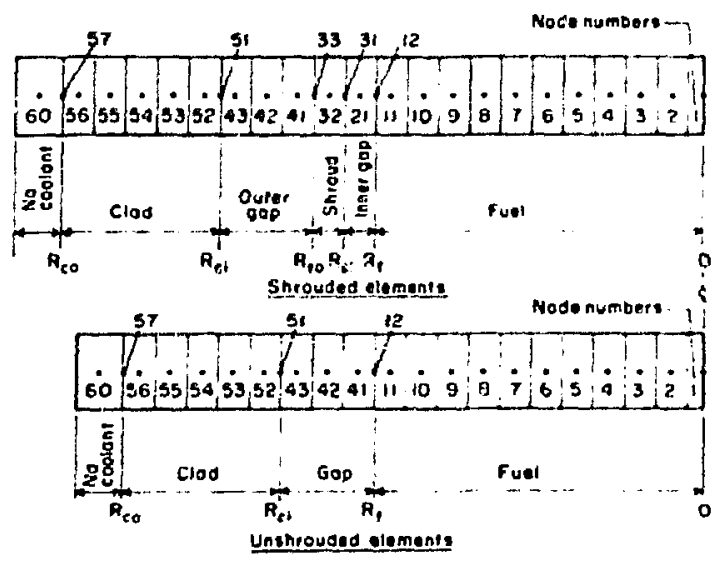

Fig. 2. Node geometry for heat tranofer calculations.

break and cominue to expand with the fuel. This occurred for the tantalum ahroud oince tantaium has a relatively low thermul expenalon coefficient. The volume chenge on molting of the fuel is eleo accounted for by a modiat therall oxpandion coofficient in the molting, range. This volume increses does not sccount for frothing of the fuel, but Is eolely a denalty chango on melting. The heate of as "Ing of the fuel and ahroud are congldered using adJusts. sat capacitieg over the melting rangs.

sfinition of what cccurs once the uuel and ahroud

melt is tifficult. For the purpose of temperature

calculatlo vo modalo ware exanined. In the

flret model ; . fuel and shroud pore assumed to 
maintaln thelr structural integrity even though they had melted, 1.e., no slumping was allowed. Calculatlons were performed with the modol for the etalnleas oteel shrouded element only. The thermal expansion ard volume change on melting of the fuel and ehroud were not sufflcient to close the gas bond, so that the fuel and ghroud attained a hlgh ateaty etate temperature. It lo felt that this Io an overly conservatuve model which beare no resemblance to what wll actually occur, but the calculations were performed to provide some feeling for the Influence of the model agsumptions on the temmeratures calculated. Results are shown is section 3.3.

The second model used allowe fuel slumping but ls still considered consorvative. The fuel was assumed to malntein ite etructural integrity untll the fuel aurfece ternporature wes above Its liquidus temperature, $2440^{\circ} \mathrm{C}$. After thls polnt, the fual was allowed a speciflc time to slump out to the slad. depending on the condition of the ohroud. If the shroad had melted, 0.1 s was allowed for the molten fuel and shroud to slump to the clad. This case covers the stalnless steal. iron, and vanadlum shrouds. If the shroud had not melted, 0.5 a was allowed for the nzolten fuel to slump through the shroud alots to the clad. Thle cape covers the tantalum shroud. The unshrouded eiements wore aleo allowed 0.1 a to elump to the clad. These siumping times are considored conservative estimates of the if are required for the molten fuel to move the short distances involved. They are greater than the estimetes used in similer calculatlons of the molting of EBR-II motal fual. ${ }^{7}$ fubtiflcation for these time estimates is presented in Appendix B.

Once the fuel or ehroud has contacted the cladding. a heat trangfer cocffic lent must be defined betwoen the cintact surfaces. The following aseumptions were used:

a. If two mitten eurfices contact $(\theta . \mathrm{B}$. fuel and ah:oud) or if a molten surface contacts a solld eurface, a contact coeffictent of $28.4 \mathrm{~kW} / \mathrm{m}^{2}{ }^{\circ} \mathrm{C}\left(5000 \mathrm{Btu} / \mathrm{h} \mathrm{ft}^{20} \mathrm{~F}\right)$ wax used.

b. If two solid eurfaces contact, a comact coefficlent of $5.7 \mathrm{~kW} / \mathrm{m}^{2}{ }^{\circ} \mathrm{C}\left(1000 \mathrm{Btu} / \mathrm{h} \mathrm{ft}{ }^{\circ} \mathrm{F}\right)$ wes ueed, c. When molten fuel contacted the clad through the still solld shroud tube, a contact coefficlent of $5.7 \mathrm{~kW} / \mathrm{m}^{2}{ }^{\circ} \mathrm{C}\left(1000 \mathrm{Btu} / \mathrm{h} \mathrm{ft}{ }^{2} \mathrm{O}_{\mathrm{F}}\right)$ was ueed to approxdmate the chance of reduced contact area (the ehroud tuber have $25 \%$ slot ares), and

d. cece molten fuel or shroud material has contacted the clad, the contact ond mi intained.

The chotce of $28.4 \mathrm{~kW} / \mathrm{m}^{2}{ }^{\circ} \mathrm{C}$ for $\mathrm{P}$. soild-Lquid contact coefficlent Is conservative for calculating peak futl temperatures. Thls value is noar the upper limlt obeerved for solld-solid contact ${ }^{5}$ and much less than values assumed to model molten fuel-clad contect with EBR-C metal fuel. 7 A low value for the conthictance will reotrict heat transfer and thits predict bigh fuel temperatures. Fer the calculation of pask clad temperatures following slumping of the fuel, the congervaitve predictlons will reeult from large contact coefficients. To cover this limlt, the peak cled temperatures following sluniphg in an unshrouded element were aleo calculated using a contact coefficlent of $284 \mathrm{~kW} / \mathrm{m}^{2}{ }^{\circ} \mathrm{C}(50,000 \mathrm{Btu} /$ $h f^{2} o_{F}$ ). The unshrouded element calculation was done since it predicts the highest peak clad temperature followIng slumping. Thly velue for the contact coefficient approaches perfect thermal cortact between the molten fuel and clad and provides upper limit estimates of the peak clad temperatures. The cholce of $5.7 \mathrm{~kW} / \mathrm{m}^{20} \mathrm{C}$ for solid-solld contact is in the range of experimentally obeerved contect coefilclents for eollds. ${ }^{8}$ None of the calculational results lo senaltive to this cholce.

\subsection{Maxdmum Fuel and Claddint Temperatures}

Heat transfer caiculations were performed at two core locatlons, the core midplane where the element power is highest, and the top of the core where the codium coolant temperature lo highest. At the core midplane. the linear power was assumed to be $125 \mathrm{~kW} / \mathrm{m}$ and the sodium temperature $450^{\circ} \mathrm{C}$. At the top of the core, the linear power was assunced to be $110 \mathrm{~kW} / \mathrm{m}$ and the sodlum temperature $540^{\circ} \mathrm{C}$. The linear powers are approximately $14 \%$ above the linear power of the highest powered element. Thlo conservative assumption was made to eccount for uncertalnties in resctor porror and fission rates in the elements. 
The major uncertainty in property data is the fiel thermal confuctivity. To estimate the effect of this uncertalnty, calculations were performed using fuel thermal conductivitles of $+20 \%$ and $-20 \%$ in addition to the nominel values listed in Appendix A.

Table $\Gamma$. liets the maximum fuel (centerline) temperatures calculated for all the case. considered. For the cases where molten fuel slumping was allowed. the tantalum shrouded element shows the maxiraum fuel temperatures. This is due to the longer slumping time set for this case and the lower contact coefflclent uned once molten fuel-clad contact was established. The results for the unshrouded nnd stalniess steel shrouded elements where slumping was allowed are quite simillar. The results for the stainless steel shrouded element, where slumping was not allowed, are approximately $400^{\circ} \mathrm{C}$ higher than the simllar cases where slumplng was allowed. The small difference is mainly due to the fact that by the time slumping starts the fuel temperaturas are beginning to peak out.

Figure 3 shows a plot of element temperatures as a function of time for the stalnless steel shrouded element with the nominal fuel conductivity at the top of the core, with slumping allowed. Curve 1 is the fuel center, curve 2 is the fuel surface, curve 3 is the shrolid mid-radius, and curve is the clad inside surface. Shroud melting starts at about $1.1 \mathrm{~s}$, fuel melting starts in the center at about $1.6 \mathrm{~g}$, fuel-shroud contsct occurs at $2.5 \mathrm{~g}$, fuel and shroud slumping starts at $3.15 \mathrm{~s}$, and contact with the clad is established at $3.25 \mathrm{~s}$. Thu peak fuel iemperature occurs in the center at about $3.4 \mathrm{~s}$. Figure 4 shows a plot fo: the same conditions except that slumping was not allowed. Shmud melting, fuel melting, and fuel-shroud contact ocsur as in the previous case, but the molten fuel and shroud are assumed to maintain thelr integrity and not contact the clad.

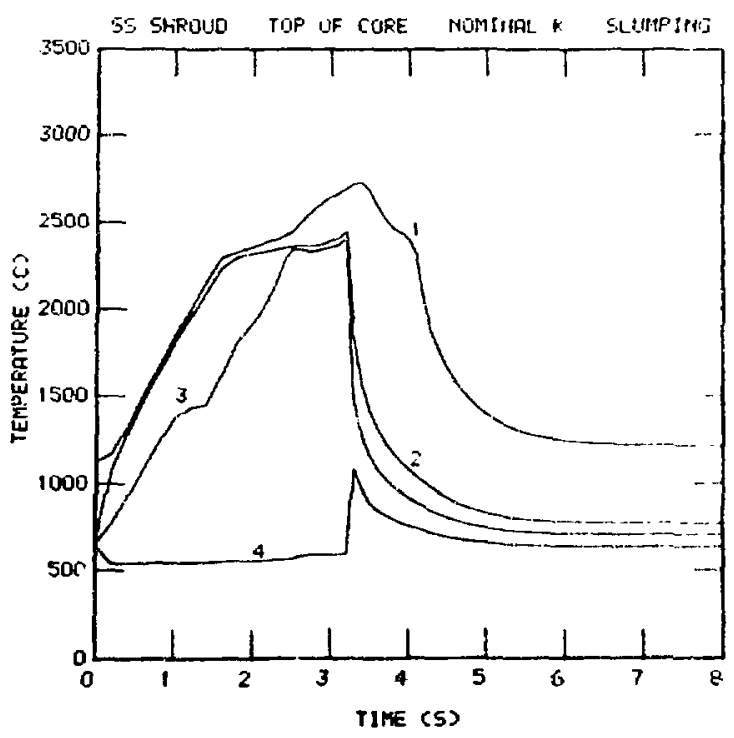

Fig. 3. Fuel element temperatures as a function of time following 1088 of bond with slumplng allowed. (Curve 1 ie fuel center, curve 2 is fuel surface, curve $3 \mathrm{lr}$, shroud mid-radlus, and curve 4 is clad luside surface.)



Fig. 4. Fuel element temperatures as a function of time following loss of bond with no slumping allowed. (Curve 1 is fuel center, curve 2 lo fuel surface, curve 3 is ohroud mid-radius, and curve 4 is clad Inside surface.) 
TABLE IV

MAXIMUM FUEL TEMPERATURES

\begin{tabular}{|c|c|c|c|c|}
\hline Shroud & $\begin{array}{c}\text { Fuel } \\
\text { Slumping }\end{array}$ & $\begin{array}{c}\text { Core } \\
\text { Location }\end{array}$ & $\begin{array}{c}\text { Fuel } \\
\text { Conductivity }\end{array}$ & $\begin{array}{l}\text { Maximum Fuel } \\
\text { Iemp. }{ }^{\circ} \mathrm{C}\end{array}$ \\
\hline \multirow[t]{12}{*}{ Stainlese Stral } & Yeg & $M$ & $\mathbf{N}$ & 2775 \\
\hline & Yo8 & $\mathbf{M}$ & $+20 \%$ & 2724 \\
\hline & Yes & $M$ & $-20 \%$ & 2842 \\
\hline & Yes & $\mathbf{T}$ & $\mathbf{N}$ & 2731 \\
\hline & Yes & $\mathrm{T}$ & $+20 \%$ & 2689 \\
\hline & Yes & $\mathrm{T}$ & $-20 \%$ & 2901 \\
\hline & No & $M$ & s. & 3163 \\
\hline & No & $M$ & $+20 \%$ & 3095 \\
\hline & No & $M$ & $-20 \%$ & 3264 \\
\hline & No & $T$ & $\mathrm{~N}$ & 3111 \\
\hline & No & $\mathrm{T}$ & $+20 \%$ & 3058 \\
\hline & No & $\mathrm{T}$ & $-20 \%$ & 3195 \\
\hline \multirow[t]{4}{*}{ None } & Yes & $\mathbf{M}$ & $n$ & 2702 \\
\hline & Yes & I & $\mathbf{N}$ & 2677 \\
\hline & Yor & $\mathrm{T}$ & +200 & 2648 \\
\hline & Yes & $\mathrm{I}$ & $-20 \%$ & 2720 \\
\hline \multirow[t]{4}{*}{ Tantalum } & Yes & $\mathbf{M}$ & $\mathbf{N}$ & 3013 \\
\hline & Yos & $\mathbf{T}$ & $\mathbf{N}$ & 2950 \\
\hline & Yeg & $\mathrm{T}$ & $+20 \mathrm{~g}$ & 2918 \\
\hline & Ye8 & $\mathbf{T}$ & $-20 \%$ & 2996 \\
\hline
\end{tabular}






Fig. 5. Clad temperatures as a function of time after molten-fuel-clad contact for nominal and high contact coefficients.

The maximum clad temperatures calculated were for the unshrouded element, where molten fuel contacts the clad directly. Flgure 5 shows a plot of clad temperatures as a function of time for an unshrouded eloment at the top of the core. The nominal contact coefficlent is $28.4 \mathrm{~kW} / \mathrm{m}^{2}{ }^{\circ} \mathrm{C}$, while the high contact coefficient is $284 \mathrm{~kW} / \mathrm{m}^{2}{ }^{\circ} \mathrm{C}$. The insite surface temperature of the clad is above the melting range for a few milliseconds after contact, with the hilgh contact coefficlent. With the nominal contact coefficient, the entire clad is always below the melting range. It should be emphasized that the high contact coefficlent is a conservatlve limiting case, 1. e., it is essentially perfiect contact between the molten fuel and clad.

\section{SODIUM COULANT TEMFERATURES FROM MOLTEN FUEL COOLANT INTERACTION}

In this section, the molten fuel tomperatures calcu-

lated in Section a are used to calculate possible sodium coolant temperatures resulting from an interaction of molten futl and sodium. These calculations are almed at estimating the likelinood of a homogeneous vapor explosion $^{9}$ or the possibility of bulk heating of the sodium above lte bolling point. There are two temperature limits of interest for the sodium coolant. The first is the minlmum sodlum bolling temperature in the subassembly. The sodium pressure at the subassembly exdt is approximately $1.5 \mathrm{~atm}$ (abs). To limit sodium coolent bolling at this pressire, the bulk sodium temperatures should be less than $925^{\circ} \mathrm{C}$. The second limit, the homogeneous nucleation tenziperature of sodium, is $2300 \mathrm{~K}\left(2027^{\circ} \mathrm{C}\right)$. Even short time losal sodilum temperatures above this limit san caupe raxid vaporization and possible shock waves in the sodlum.

Section 4.1 discusses the calculation of the interface temperaiure between molten fuel and sodium. Section 4.2 discusses the calculation of bulk sodium coolant temperatures due to possible loge of molten fuel into the coolant channels.

4.1 Instantanoous Interface Temperatures

Ueing a model developed by Fauske, ${ }^{10}$ the potential for achieving an instantaneous molten fuel-sodiun interface temperature above the homogeneous nucleation temperature can be evaluated with the expression

$$
\frac{T_{i}-T_{B}}{T_{f}-T_{1}}=\left[\frac{\left(k p c_{p_{f}}\right.}{\left(k p c_{p^{\prime}}\right)^{\prime}}\right]^{\frac{1}{2}} \text {, }
$$

where $T$ ls the temperature, $k$ is the thermal conductiv Ity. o is the density, $c_{p}$ is the heat capacity, and subscripts $s, f$, and $i$ refer to sodium, fuel, and the fuelsodium interface, respectively. Interface temperatures were calculated for the maximum fuel temperatures shown In Table IV. This is a conservative assumption since the maximum fuel temperatures occur at the fuel centerline. Temperatures at the fuel surface adjacent to the clad fallure axe approximately $300^{\circ} \mathrm{C}$ below the fuel centerline temperatures. The sodium and fuel properties liated in Appendix A were used in the calculation. When an increased or decreased fuel thermal conductivity was ues: to calculate fuel temperatures, this game conducUvity was used to evaluate the interface temperature. Figure 6 shows a plot of $\Delta T=2027^{\circ} \mathrm{C}-\mathrm{T}_{1}$ as a function of fuel thermal conductivity variation around its nominal values. The quantity $\Delta T$ can be considered as the eafety margin between the calculated sodium interface temperatures and the homogeneous nucleation temperature of Bodium. All the interface temperatures calculated are below the homogeneous nucleation temperature. The highest fuel temperatures calculated were at the core mitplene (see Table IV). But the highest interface temperatures were calculated at the top of the core due 


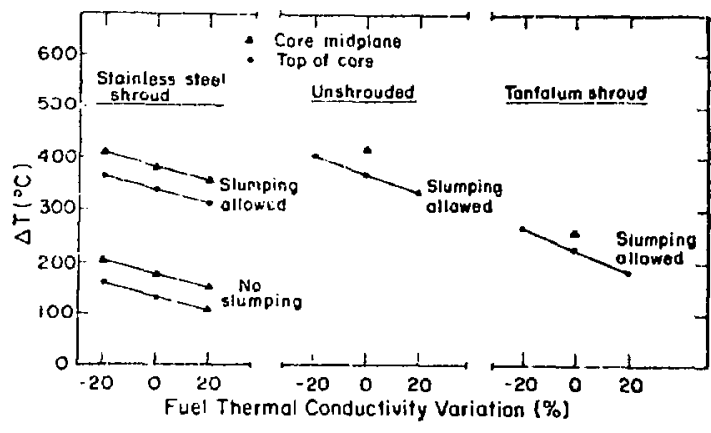

Fig. 6. Safety margin ( $\Delta^{\prime} T$ ) as a function of fuel thermal conductivity for a variety of conditions.

to the higher sodium coolant temperatures at this lucation. Thus, the smallest margin of safety (smallest $\Delta T$ ) exdsts at the top of the core. As the fuel thermal conductivity increases, the maximum fuel temyeratures calculated decrease (see Table IV). But this decrease in $T_{f}$ is more than offset by an increase in the property ratio in Eq. (1). Thua, the interface temperatures increase (values of $\Delta T$ decrease) as the fuel thermal conductivity Increases.

4.2 Bulk Heating of the Sodium

Even though the instantancous interface temperature resulting from molten fuel-sodium contact is below the homogeneous nucleation temperature of sodium, it is possible that bulk heating of the aodium can ralge its temperature above the bolling point. Bulk heating of the sodium will depend on the amount of molten fuel that is lost from the element and the rate of loss, as well as the molten fuel temperature. Esti: 1ates of the molten fuel lose in turn depend on the internel element pressure and the clad failure slze.

The most uncerteln quantity required for bulk hcatIng estimates is the size of the clad failure. A number of falled eiements with uranlum-plutonium carbide fuel have been examined after irradiation. Moet nave come from encapsulated experiments in EBR- $\square,{ }^{11}$ but one element from the U5100 Sories (U248) has failed and is being exanilied. $^{12}$ Five encapsulated elements (K-36B, $K-45$, $\mathrm{K}-46, \mathrm{~B}-3-3$, and $\mathrm{U} 194$ ) have been examined which were known failures (fission gas was found in the capsule out- side the element clad), but the fallure point was never located. ${ }^{11}$ One of the elements $(K-45)$ was pressurized to 27 atm whlle heating the sodium bond above its meltin point. These results Indicate an extremely smail failure but are not useful for a quantitative estimate of the fallure size. A number of Eeverely falled elements with large cracks in the clad and areas of melted clad have also been fou id during postirradiation examination of encapoulated fivel elements. A description of a mechanIsm by whlch slightly falled elements can progress to severe fallures through lateraction with the capsule has been presented. 11 The advanced ftol element failures observed to date have piobably all started as slight failures. Continued irradlation after the initial fallure produced the severe fallures. Elemente which are not encapsulated, such as the US100 Series, are not subject to this aame mechanlom of fallure progression from slight to severe.

Data obtained during the postl rradiation examinatIon of the U248 element are usoful for estimating the size of the initial fellure. ${ }^{12}$ The element was pressurized internally and immersed in liquid. A sraall leak started at 24 atm preseure. During eubsequent pressure testing, the fallure leaked noticably at pressures as low as 17 atm. Data on the internal pressure loss of the element whlle it was closed off were used to estimate the fallure size. For the calculation, the failure pras assum ed to be an orifice. The orfice flow formula used was 13

$$
Q=C A \sqrt{2 \Delta P / \rho}
$$

where $Q$ is the flow rate, $A$ se the hole area, $C$ is the orl fice coefficient (0.6), $\Delta P$ ls the pressure differenise, and $p$ is the density. The calculisted slze of the failure was $4 \times .0^{-6} \mathrm{~mm}^{2}$ at 24 atm end $1 \times 10^{-6} \mathrm{~mm}^{2}$ at 17 atm. The fact that the apparent failure size increases with increasing pressure is probably an indication that intexual pressure tends to open the crack.

For the purpose of further calculation, two effective clad fallure olzes have been chosen, a moderate fallure aize of $6 \times 10^{-1} \mathrm{~mm}^{2}$ (about two orders of magnitude Ereater than the estimate above) and a large failure size 
of $6 \times 10^{-2} \mathrm{~mm}^{2}$ (about four orders of magnitude greater than the estimate above). These sizes are in the range used to characterize oxide element falures. 14

To estimate the rate at which molten fuel might be lost through a moderate and lerge fallure, EG. (2) was again used with a molten fuel density of $10 \mathrm{~g} / \mathrm{cm}^{3}$ and a. press'se differential of $70 \mathrm{~atm}$. This esentialiy assumes complete fission gas release. Under these conditions the rate of molten fuel loss through a moderate faliure would be $0.013 \mathrm{~cm}^{3} / \mathrm{s}$, and through a large failure would be 1.3 $\mathrm{cm}^{3} / \mathrm{s}$.

These estimates of molten fuel loss rates can be used in two ways, to estimate the total amount of molten fuel which might be lost from the element, and to estlmate the bulk neating of the sodium coolant. As described in Section 3.2, when molten fuel contasts the cladding, the fuel is rapidly quecched. Solid fuel will plug any clad failure in a short time. To compute the time required to plug the fallure, estimates of the linear fallure size and the rate at which the solld-liquid interface in tha fuel moves away from the fuel-clad interface are required. Assuming the clad fallures are circular (which is conservative since it gives the largest linear dimension) the radius of the moderate fallure is $1.4 \times 10^{-2} \mathrm{~mm}$ and the radius of the large fallure is $1.4 \times 10^{-1} \mathrm{~mm}$. The rate at wisich the solid-liquid interface in the fuel moves was obtained from the heat transfer model described in Section 3.2. For the contact of molten fuel (eurface temperature $2520^{\circ} \mathrm{C}$ ) with clad, the interface velocity is approximately $6.7 \mathrm{~mm} / \mathrm{s}$. An estimate of the time required to plug the moderate failure is

$$
\left(1.4 \times 10^{-2} \mathrm{~mm}\right) /(6.7 \mathrm{~mm} / \mathrm{s})=2 \mathrm{~ms} \text {, }
$$

and to plug the large fallure is $20 \mathrm{~ms}$. Using these time estimates, the moderate follure would release

$$
\left(0.013 \mathrm{~cm}^{3} / \mathrm{s}\right)\left(10 \mathrm{~g} / \mathrm{cm}^{3}\right)(0.002 \mathrm{~g})=2.6 \times 10^{-4} \mathrm{~g}
$$

of fuel whlle the large failure would release $0.26 \mathrm{~g}$ of fuel.

The bulk heating of the sodium coolant will depend on the rate of lose of molten ruel from the element and the volume of eodium coolant with which it mbxes. A conservative assumption would be that moiten fuel is lost to a central subchan rel of the subassembly and does not mix with other subchannels. The sodium flow in a central subchannel of the subassembly $1888 \mathrm{~cm}^{3} / \mathrm{a}$. The molten fuel lose rates are small and should not perturb the coolant flow cates significantly. If molten fuel of an average temperature $T_{f}$ is mixed with sodium of temperature $T_{s}$, the final equilibrium temperature $T_{\theta}$ of the mixture can be found from an energy balance,

$$
m\left(x c_{p}\right)_{f}\left(T_{f}-T_{e}\right)=(1-m)\left(p c_{p}\right)_{g}\left(T_{e}-T_{g}\right),
$$

where $m$ is the volume fraction of fuel in the muxture. For the moderate fallure

$$
\operatorname{In} \approx\left(0.019 \mathrm{~cm}^{3} / \mathrm{s}\right) /\left(88 \mathrm{~cm}^{3} / 8\right)=1.5 \times 10^{-6} \text {, }
$$

and for a large fallure $m \approx 1.5 \times 10^{-2}$. This calculation of $m$ ignores axial mixing and is, thus, coneervative from that standpoiut. For the calculations It was assumed that $\mathrm{T}_{\mathrm{f}}=3000^{\circ} \mathrm{C}, \mathrm{T}_{\mathrm{B}}=540^{\circ} \mathrm{C},\left(\mathrm{pc} \cdot \mathrm{f}=3.77 \mathrm{~J} / \mathrm{cm}^{3}{ }^{\circ} \mathrm{C}\right.$, and

$$
\left(\rho c_{p}\right)_{s}=0.837 \mathrm{~J} / \mathrm{cm}^{30}{ }^{\circ} \mathrm{C} \text {. }
$$

The final equilibrlum temperature of the fuel-sodium mixture is $542^{\circ} \mathrm{C}$ for the moderate fallure and $700^{\circ} \mathrm{C}$ for the large fallure. Both of these temperatures are below the bolling temperaturc of sodium at the subassembly outJet $\left(925^{\circ} \mathrm{C}\right)$.

\section{DISCUSSION}

This report aesesses the consequences of a loss of sodium bond from a uranturn-plutonium carbide fueled element during normal ateady etate operation. The elements considered are typical of those currently being irradiated in EBR-II. The analysis includes elements with and without shroud tubes. Sodium bond loss Into the coolant through a clad fallure was the mechanisrs considered.

Maxirium fuel temperatures were calculated and found to be in the range of $2700^{\circ} \mathrm{C}$ to $3000^{\circ} \mathrm{C}$ when fuel slumping is accounted for. If essentially perfect contact was allowed, Inside clad surface temperatures above the melting range were celculated following contact with molten fuel. If less conservative estimates of the contact coefficient were used in the calculation, no clad melting was predicted. Sodium coolant temperatures calculated for instaneous contast with molten fuel and from bulk 
heatlyg were lound to be below the homogeneous nucleation temperature for sodium. Bulk sodium coolant teriperatures were also below the bolling temperature of sodium at the exit of the gubassembly.

The peak cladding temperatures calculated here indlcate the possibllity of Iaside surface melting. There are two experiments which relate to this question. Gulf United Nuclear Fuels Corporation (GUNF) performed a set of GETR irradiations whlch examined the consequences of sodium bond defects and loss of bond. ${ }^{15}$ Evidence of an interaction (probably due to inside clad surface meltingl to about $0.05 \mathrm{~mm}$ out of $0.38 \mathrm{~mm}$ total clad thickness could bo seen in some instances. No clad failures occurred in this group of elements. A LASL encapsulated element in EBR- II (K-49) was a severe failure and showed evidence of contact between possibly molten fuel and the capsule wall (ư is). 11 There was no evidence of capsule melting or no interaction between the fuel and the capsule wall. The GUNF experiments tend to sulustantiate the calculatlons performed here, i. e., Inside clad surface melting may occir from contact with molten fuel, but it is rapid!y quenched as long as sodium coolant flow is maintained on the outside of the clad.

The molten fuel-coolant interaction (MFCI) calculations indicatc that the sodium temperatures resulting from instantaneous contact with molten fuel will he $300^{\circ} \mathrm{C}$ to $400^{\circ} \mathrm{C}$ below tue homogeneous nucleation temperature of sodium for ur-hrouded elements or those shrouded in stainless stec 1 Iron, or vanadium. The tantalum shrouded element may have a smaller margin of safety. This result indicatos that small emounts of fuel ejected from a clad fallure will not cauge homogeneous vaporization of the sodium coolus:t. Further calculations also indicate that bulk heatir ; of the sodium coolant by molten fuel ofll not cause homugeneous vaporization or boiling of the sodium coclant.

Expersictents performed by Atomics Irternational have gome bear'sg on these calculations. ${ }^{16}$ TREAT tests overpowered sodium-bonded UC fuel in stainless stegl clad which was ellr rounded by sodium and a heat sink. In one test, centerline fuel temperatures of $3150^{\circ} \mathrm{C}$, with some Indications of temperatures as high as $3800^{\circ} \mathrm{C}$, were measured. The maximum pressure measured in the capsule was less than 13 atm. This transient overpower completely destroyed the element. Although these test results cannot be directly translated to the calcularions presented here, they showed no significant MFCI under analogous conditions.

As concluding remarks, the gerierally constrvative nature of the analysis presented here should $D \in r \in-$ fterated. In the calculation of the maximum ruel iemperatures attained following the loss of bond, the effect of using initial gap sizes, concentric fuel und ciad, complete loss of bond sodium, end of life (lowest thermal conductivity) plenum gas replacing the sodium, no axa inchuction, power that is $14 \sigma_{0}$ above nomina!, long slumpung time for the fuel, and no frothing of the ruel on melting are all conservative. A partial retention of the sodium bond, significant axial conduction ( div to a slow lass of bond), eccentric fuel in tine claa, or shorter sintivirg times would all tend to redice the riavizum. fiel temperatures calculated. An allowance for irothing (die to rotained fission gas) of the central portion of the dis: a: temperatures above its solidus temperature might ever prevent melting os the outer region of the ruel. For these reasons the maxivim fuel temperatures caiclibied sicu.d be considered as upper limits, and not necessarily repiecentatlve of whai wo: ld be attained following \& loss of bond.

The estin:ates of the amount of fuel that could be lost through a clad failure and the loss rate are more apeculative than the maximum fuel temperature calculations, but still represent a conservatıve calculation. Current evidence buout initial clad fullires indickites wat they are much in:ible $\mathrm{i}$ than the hole sizes asslimed in this analysis. The estimates presented should be considered as upper l.raits for initial failures, where the lower limit is no tuet icoì.

\section{ACKNOWLEDGMENTS}

i'he author wishes to acknowledge the many discussions he had with John Barner concerning the ideas communicated in this report. 


\section{APPENDD A}

\section{PROPERTY DATA}

This appendix containg the property data used in the heat transfer calculations. Table A-1 listo the (U. 8 Pu. ${ }_{2}$ ) C fuel property deta. Fuel thermal conductivity was obtained from an evaluation of experimental data from five sources. $17-21$ Prior to evaluation, all the data were correrted to $100 \%$ theoretical donsity using the expression

$$
k_{p}=k_{0} \frac{(1-p)}{(1+p)}
$$

where $k_{o}$ and $k_{p}$ are the conductivities at zero pore volume fraction (100\% theoretical dengity), and at pore volLime fraction $\mathrm{g}$, respectively. The volumetric heat capacity is the procuct of the heat capacity and density. Fuel density was calculated from the theoretical density of (U. ${ }_{8}$ Pu. $\left.{ }_{2}\right) \mathrm{C}$ at $25^{\circ} \mathrm{C}\left(13.43 \mathrm{~g} / \mathrm{cm}^{3}\right.$ ) and of $\left(\mathrm{U} .{ }_{8} \mathrm{Pu} . \mathrm{g}_{2} \mathrm{C}_{4}\right.$ at $25^{\circ} \mathrm{C}\left(12.72 \mathrm{~g} / \mathrm{cm}^{3}\right)$. The effect of temperature on density was estimated from thermal expansion coefficient data, ${ }^{22}$ and the density chazge on melting was estimated from data on inorganic salts wth a slmllar struciure. 23 The beat capacity of (U. 8 Pu. 2 ) C fiel was calculated from the heat capacities of UC and PuC comblned according to their mole fractions. 24 No emissivity data were found for carblde fuel, so a value of 0.5 was est mated. The liquidus and solldus temperatures of (U. $\left.{ }_{B} \mathrm{Pu} .{ }_{2}\right) \mathrm{C}$ have beer. Ireasured. ${ }^{25}$ The heat of fusion of (U. $\mathrm{Pu}_{2}$ ) $\mathrm{C}$ was estimated from an entropy of fusion of $5.5 \mathrm{eu} .^{26}$

Table A-2 lists the stainless sted property data. These data can be used for 304 or 316 stainless ateel. Standard reference sources were used for the thermal concuctivity, ${ }^{27}$ heat capacity, ${ }^{28}$ thermal expansion coefflclent, ${ }^{29}$ density, ${ }^{29}$ emissivity, ${ }^{30}$ and melting temperatures ${ }^{31}$ of stainless stegl. The heat of fuslon was estimated from the heats of fusion of the component elements. 32

Table A-3 llats the tantalum property data. Standard reference sources were used for the thermal conductivity, ${ }^{27}$ heat capacity, ${ }^{28}$ thermal expansion coefficient, ${ }^{33}$ density, ${ }^{32}$ emissivity, ${ }^{30}$ and melting polnt. ${ }^{27}$

Table A-4 lists the llquid sodium properties used. All data were obtained from a compilation of sodilum property data. $^{34}$

Table A-5 liste the properties of belium, argon, and fission gas used in the calculations. Flssion gas was assumed to be $15 \%$ krpyton and $85 \%$ xenon. Thermal conductivity data for all four noble gases were taken from the same compllation. 35 Data for krypton and xenon were only avallable up to about $500^{\circ} \mathrm{C}$. In the temperature range from $200^{\circ} \mathrm{C}$ to $500^{\circ} \mathrm{C}$ the ratio of the conductivity of krypton to that of argon Ls constant at 0.55 , while the ratio of the conductivity of xenon to that of argon is constant at 0.35. Assuming these values hold over the entire temperature range of interest, and that the conductlvity of a gas mixture can be obtained from the conductivities of its pure components by mole fraction averaging,

$$
k_{f g}=(0.15)(0.55) k_{A}+(0.85)(0.35) k_{A}=0.38 k_{A} \text {. }
$$
where $\mathrm{k}_{\mathrm{fg}}$ and $\mathrm{k}_{\mathrm{A}}$ are the thermal conductivities of flesion gas and argon, respectively. Heat capacity data for all the gases were obtained from the same source. ${ }^{36}$ 
TABLE A-1

FUEL PROPERTY DATA

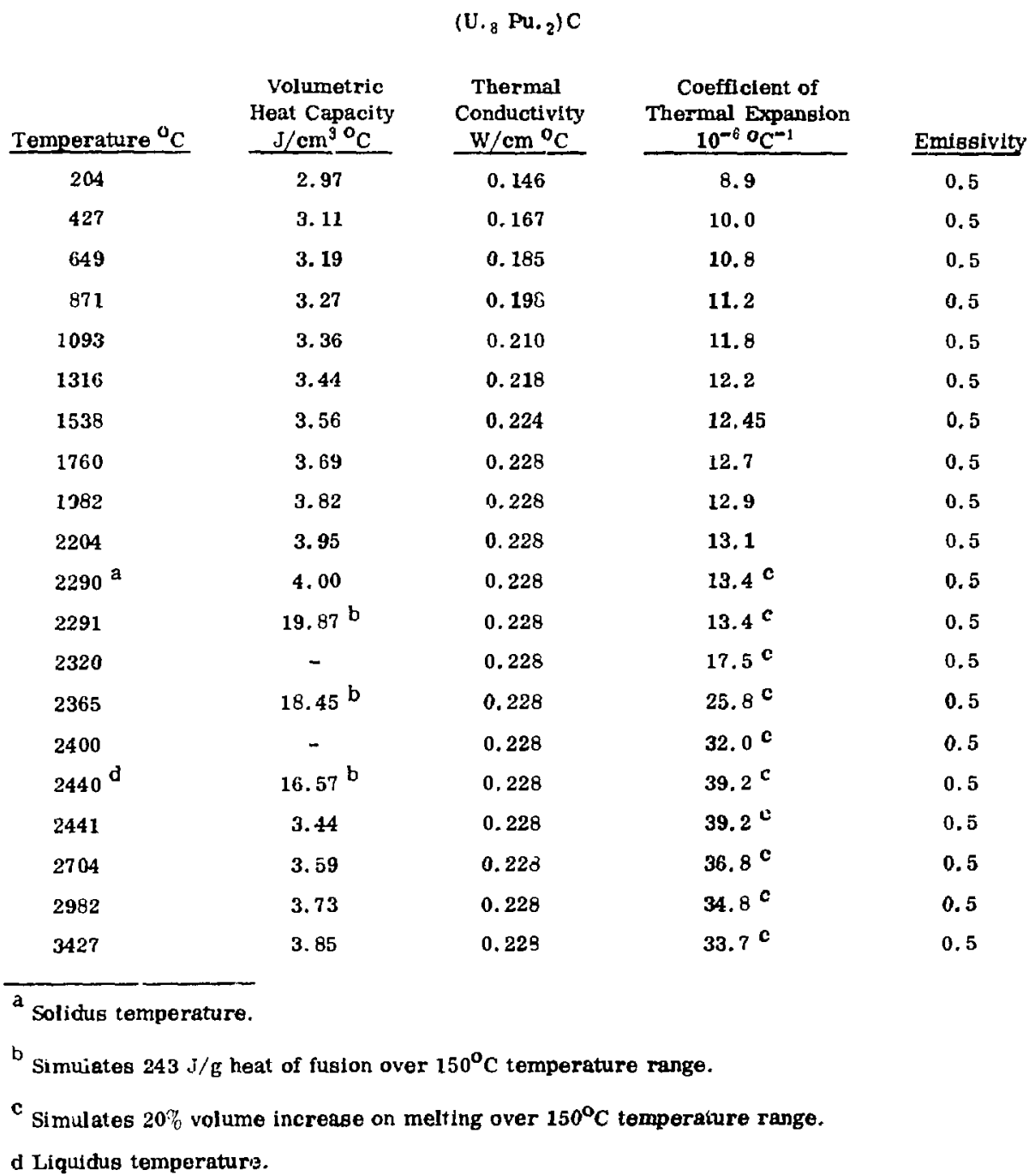


TABIE $A-2$

STAINLESS STEEL PROPERTIES

\begin{tabular}{|c|c|c|c|c|}
\hline Tomperature ${ }^{\circ} \mathrm{C}$ & $\begin{array}{l}\text { Volumetric } \\
\text { Heat Capacity } \\
\mathrm{J} / \mathrm{cm}^{3{ }^{\circ} \mathrm{C}} \\
\end{array}$ & $\begin{array}{l}\text { Thermal } \\
\text { Conductivity } \\
\mathrm{W} / \mathrm{cm}^{\circ} \mathrm{C} \\
\end{array}$ & $\begin{array}{c}\begin{array}{c}\text { Coofficlent of } \\
\text { Therma Expansion } \\
10^{-6} 0^{0} \mathrm{C}^{-1} \\
\end{array}\end{array}$ & Emtostutty \\
\hline 204 & 3.03 & 0.167 & 16.9 & 0.2 \\
\hline 427 & 3.12 & 0.203 & 17.8 & 0.2 \\
\hline 649 & 3.34 & 0.241 & 18.7 & 0.2 \\
\hline 871 & 3.62 & 0.276 & 18.6 & 0.2 \\
\hline 1093 & 3.60 & 0.308 & 20.4 & 0.2 \\
\hline 1316 & 3.74 & 0.341 & 21.2 & 0.2 \\
\hline $1427^{a}$ & 3.74 & 0.341 & 21.7 & 0.2 \\
\hline 1428 & $74.90^{b}$ & 0.341 & 21.7 & 0.2 \\
\hline 1453 & $74.90^{\mathrm{b}}$ & 0.341 & 21.9 & 0.2 \\
\hline $1454^{c}$ & 3.77 & 0.341 & 21.9 & 0.2 \\
\hline 1650 & 3.77 & 0.341 & 22.0 & 0.2 \\
\hline ¿idus tempe & & & & \\
\hline
\end{tabular}

TABLE $A-3$

TANTALUM PROPERTIES

\begin{tabular}{|c|c|c|c|c|}
\hline Temperature ${ }^{\circ} \mathrm{C}$ &  & $\begin{array}{l}\text { Thermal } \\
\text { Conductivity } \\
\text { W/em }{ }^{\circ} \mathrm{C}\end{array}$ & $\begin{array}{c}\text { Coefficient of } \\
\text { Thermal Expansion } \\
10^{-6} 0_{0} C^{-1} \\
\end{array}$ & Emlssivity \\
\hline 204 & 2.41 & 0.582 & 6.5 & 0.2 \\
\hline 427 & 2.44 & 0.590 & 6.6 & 0.2 \\
\hline 649 & 2.47 & 0.598 & 6.6 & 0.2 \\
\hline 871 & 2.53 & 0.607 & 6.7 & 0.2 \\
\hline 1093 & 2.60 & 0.615 & 6.8 & 0.2 \\
\hline 1316 & 2.67 & 0.623 & 6.9 & 0.2 \\
\hline 1538 & 2.73 & 0.632 & 7.1 & 0.2 \\
\hline 1760 & 2.80 & 0.640 & 7.4 & 0.2 \\
\hline 1982 & 2.90 & 0.649 & 7.7 & 0.2 \\
\hline 2204 & 3.01 & 0.657 & 8.0 & 0.2 \\
\hline 3426 & 3.18 & 0.665 & 8.3 & 0.2 \\
\hline 2649 & 3.48 & 0.674 & 8.6 & 0.2 \\
\hline 2871 & 4.13 & 0.682 & 8.9 & 0.2 \\
\hline $2996^{a}$ & 4.81 & 0.686 & 9.1 & 0.2 \\
\hline
\end{tabular}

aolting point. 


\section{LIQUID SODIUM PROPERTIES}

\begin{tabular}{|c|c|c|c|}
\hline Temperature ${ }^{\circ} \mathrm{C}$ & 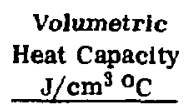 & $\begin{array}{l}\text { Thermal } \\
\text { Conductivity } \\
\mathrm{W} / \mathrm{cm}{ }^{\circ} \mathrm{C} \\
\end{array}$ & $\begin{array}{c}\text { Vapor Pressure } \\
\text { atm }\end{array}$ \\
\hline 204 & 1.209 & 0.808 & - \\
\hline 427 & 1.084 & 0.711 & $9.5 \times 10^{-4}$ \\
\hline 649 & 1.000 & 0.611 & $6.8 \times 10^{-2}$ \\
\hline 871 & 0.950 & 0.510 & 0.91 \\
\hline 982 & 0.941 & 0.473 & 2.3 \\
\hline 1093 & 0.933 & 0.435 & 5.0 \\
\hline 1204 & 0.933 & 0.402 & 3.6 \\
\hline 1316 & 0.933 & - & 16.9 \\
\hline
\end{tabular}

TABLE A-5

HEI ${ }_{\perp}$ UM, ARGON, AND FISSION GAS PROPERTIES ${ }^{a}, c$

\begin{tabular}{|c|c|c|c|}
\hline Temperature ${ }^{\circ} \mathrm{C}$ & $\begin{array}{l}\text { Hellum } \\
\text { Thermal } \\
\text { Conductivity } \\
\text { W/cm }{ }^{\circ} \mathrm{C} \\
\end{array}$ & $\begin{array}{l}\text { Fiseion Gas } \\
\text { Thermal } \\
\text { Conductivity } \\
W / \mathrm{cm}^{\circ} \mathrm{C} \\
\end{array}$ & $\begin{array}{l}\text { Argon } \\
\text { Thermal } \\
\text { Conductivity } \\
W / \mathrm{cm}^{\circ} \mathrm{C} \\
\end{array}$ \\
\hline 204 & $2.09 \times 10^{-3}$ & $9.6 \times 10^{-5}$ & $2.55 \times 10^{-s}$ \\
\hline 427 & $2.78 \times 10^{-3}$ & $1.26 \times 10^{-4}$ & $3.35 \times 10^{-4}$ \\
\hline 649 & $3.43 \times 10^{-9}$ & $1.55 \times 10^{-4}$ & $4.06 \times 10^{-4}$ \\
\hline 871 & $4.02 \times 10^{-3}$ & $1.80 \times 10^{-4}$ & $4.69 \times 10^{-4}$ \\
\hline 1093 & $4.60 \times 10^{-3}$ & $2.00 \times 10^{-4}$ & $5.23 \times 10^{-4}$ \\
\hline 1316 & $5.19 \times 10^{-3}$ & $2.22 \times 10^{-4}$ & $5.82 \times 10^{-4}$ \\
\hline 1538 & $5.73 \times 10^{-3}$ & $2.43 \times 10^{-4}$ & $6.40 \times 10^{.44}$ \\
\hline 1760 & $6.32 \times 10^{-3}$ & $2.68 \times 10^{-4}$ & $7.03 \times 10^{-9}$ \\
\hline 1982 & $6.82 \times 10^{-3}$ & $2.85 \times 10^{-4}$ & $7.49 \times 10^{-4}$ \\
\hline 2204 & $7.32 \times 10^{-3}$ & $3.05 \times 10^{-4}$ & $8.08 \times 10^{-4}$ \\
\hline 2527 & $8.08 \times 10^{-3}$ & $3.39 \times 10^{-4}$ & $8.87 \times 10^{-4}$ \\
\hline 3027 & $9.16 \times 10^{-3}$ & $3.85 \times 10^{-4}$ & $10.13 \times 10^{-4}$ \\
\hline \multicolumn{4}{|c|}{$\begin{array}{l}\text { Volumetric heat capacity of all noble gases taken as } 8.45 \times 10^{-4} \mathrm{~J} / \mathrm{cm}^{3}{ }^{\circ} \mathrm{C} \\
\text { based on a heat capacity of } 20.8 \mathrm{~J} / \text { mole }{ }^{\circ} \mathrm{C} \text { and the gas density at } 1 \mathrm{~atm} \text { and } \\
25^{\circ} \mathrm{C} \text {. }\end{array}$} \\
\hline \multicolumn{4}{|c|}{${ }^{b}$ Fission grs composition is $15 \% \mathrm{Kr}$ and $85^{\prime} \mathrm{c}$ Xe. } \\
\hline
\end{tabular}




\section{FUEL SLUMPING TIME ESTIMATE}

The time required for the molten fuel to elump out to the clad was based on a calculation of the potential energy difference between a volume of fuel before and after slumping, and the assumption that this potential ene:'gy difference was converted into kinetic energy. from which a fuel velocity could be estimated. Figure B-1 shows a diagram of a volume of fuel before and after s'umping, where $d_{0}$ and $h_{0}$ are the inltial diameter and helght, and $d_{f}$ and $h_{f}$ are the final values. Assuming there is no volume change on slumping.

$$
h_{f}=\left(d_{0} / d_{f}\right)^{2} h_{o} .
$$

The ayerage potentlal energy change per gram of material in the volume on slumping is $\left(h_{0}-h_{f}\right)$. The average kinetic energy per gram of materlals is $V^{2} / 2 g$, where $V$ Is the velocity and $g$ is the ecceleration of gravity $\left(980 \mathrm{~cm} / \mathrm{s}^{2}\right)$. Equnting the loss of potential energy with an increase in kdnetlc energy results in

$$
V=\left[\operatorname{gh}_{0}\left(1-d_{0}{ }^{2} / d_{f}{ }^{2}\right)\right]^{2} \text {. }
$$

This would be the final velocity achleved from the potent:al energy change. To calculate the slumping time, the average velocity $v_{a}$ is noeded. This was aseumed to be helf the final velocity,

$$
v_{a}=\frac{b}{p}=\left[g h_{0}\left(1-d_{0}{ }^{2} / d_{t}{ }^{2}\right)\right]^{\frac{2}{2}}
$$

The distance the fuel must move is $\left(d_{t}-d_{0}\right)$, which is the rudlal gap. Therefore, the slumping time, $t_{B}$ is

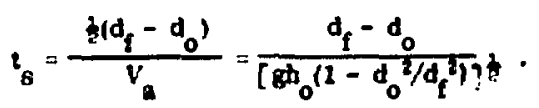

Calculatlons of the slumping time for various diametral gaps, and Initial helghts $\left(\mathrm{h}_{0}\right)$ of 1 and $10 \mathrm{~mm}$ are shown below:

$$
\begin{array}{clr}
\frac{\left(d_{f}-d_{0}\right) \mathrm{mm}}{0.05} & \frac{h_{0}=1 \mathrm{~mm}}{0.004} & \frac{t_{0}=10 \mathrm{~mm}}{0} \\
0.25 & 0.01 & 0.001 \\
0.50 & 0.014 & 0.003 \\
0.75 & 0.017 & 0.004
\end{array}
$$

The largest initlal diametrsl gap (cold) is $0.83 \mathrm{~mm}$. The largest dlametrel ga- the start of slumping is approximately $0.25 \mathrm{~mm}$. Thls occurs in the unshrouded elements. The choice of $t_{B}=0.1 \mathrm{~s}$ for the unghrouded elements and the ehrouded elements where the shroud has melted is about an order of magnitude greater than the estimste here for simllar dlametral gape. The choice of $t_{B}=0.5 \mathrm{~s}$ for abrouded elemente where the shroud has not melted is Bomewhat arbitrary, but it woo felt that some penalty must be taken for slumping through the shroud holes.

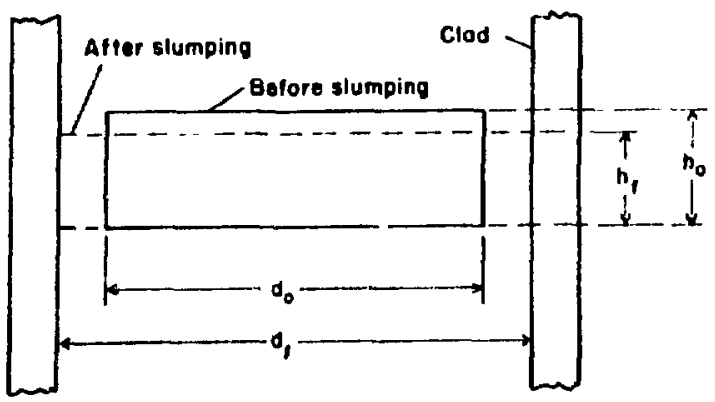

Fig. B-1. Fual olumping diagram. 


\section{REFERENCES}

1. T. W. Latimer, J. O. Berner, J. F. Kerrisk, and J. L. Green, "Steady-State Irradiation Behavior of Helium-lzonded Uranium-Plutonium Carbide," Trans. Am. Nucl. Soc. 19, 91 (1974).

2. J. O. Barner, T. W. Latimer, J. F. Kerrisk, D. Bost, and J. L. Green, "Steady-State Irradiation Behavior of Sodium-Bonded UraniumPlu:onium Carbide," Trans. Am. Nucl, Soc. 19. 91-92 (1974).

3. R. D. Baker. "Quarterly Report, Advanced Plutonium Fuels Program, January 1 through March 31, 1974," Los Alamos Scientific Laboratory report LA-5660-PR, pp. 16-18 (July 1974).

4. J. F. Kerrisk, "PINTEMP, A Computer Program for Fuel Element Design Calculatione," Los Alamos Scientific Laboratory report, IA-5868MS (February 1975).

5. "Guide for Irradiation Experiments in EBR-II," Argonne National Laboratory, EBR-ti Project, Chicago, II.

6. R. J. Connor, R. E. Kannady, Jr., and J. E. Almanza, "Adaptaiton of Chrysler Improved Numerical Differencing Analyzer to CDC 6000 Series Computers, " Martin Marietta Corporation, report $\mathrm{M}-68-22$ (November 1968 ).

7. C. E. Dickerman, P. L. Willis, R. R. Smith, P. B. llenault, R. Purviance, J. F. Boland, A. De Volpi, R. A, Noland, J. Regis, A. B. Cohen, and $C$. M. Walter, "TREAT Sodfum Loop Lxperiments on Performance of Unbonded, Unirradiated EHR-II Mark I Fuel Elements," vucl. Eng. Design 12, pp. 381-390 (1970).

8. W. M. Kohsenow and I. P llartnet, Handbook of Heat Transfer (McGraw-Hill Book Co., New York, 19731, pp. 3-14 to 3-18.

9. 1. C. Witte, "The Vapor Explosion," Journal of Metals, pp. 39-44, February 1970.

10. II, K. Fauske. "The Role of Nucleation in Vapor Explosions," Trans. Am. Nucl. Soc. 15. 813 (1972)

11. R. 1). lakker. "Quarterly Report, Advanced Plutonium liuels Jrogram. April l through fune 30. 1973, and seventh Annual Report. FY 1973," Los Alamos Scientific Laboratory report IA5390-PIR, pp. 22-2H (September 1973 ).

12. J. Q. Barner. Los Alamos Scientific laboratory, privale communication, 1974.
13. R. B. Bird, W. E. Stewart, and E. N. Lightfoot, Transport Fhenomena (John Wley and Sons, Inc. , New York, 1960), pp. 224-226.

14. L. M, MeWethy, "Fuel Faflure Predictions and Consequences," General Electric report GEAP13953, July 1973 .

15. M. H. Montgomery, "High Power and Heat Flux Irradiation of Uranium-Plutonium Carbides, " Gulf United Nuclear Fuels jorp. report GU-5294 (April 1973).

16. S. J. Stachura, M. Silberberg, and R. N. Cordy, "Uranium Carblde Translent Heating Studies Phase II," Trans. Am. Nucl. Soc. 8,305 (1965); S. J. Stachura and M. Silberberg, "The Application of Experimental Data from TREAT Meltdown Studies to Reactor Accident Analysis, "Proceedings of the Conference on Safety, Fuels, and Core Design in Large Fast Power Reactors, Argonne National Laboratory report ANL-7120, pp. \$14523 (October 1965).

17. K. W. R. Johnson and J. A. Leary, "The Thermal Conductivity of Uranjum Plutonium Carbides," Trans. Am. Nucl. Soc. 12, 591 (1969).

18. S. Bocker, R. Boucher, R, Lorenzelli, and C. Milet, "The U-Pu-C-M Carbides," in Plutonium 1970 and Other Actinides, W. N. Miner, Ed., (The Metallurgical Society of the American institute of Mining, Metallurgical and Petroleum Engineers, New Yor!, 1970) pp. 113119 ,

19. J. C. Van Craynest, J. C. Woilbacher, and J. C. Salbreax. "T". Jrmal Conductivity of Mixed Uranium and Plutonium Carbides, Nitrides, and Carbonitrides," Proceedings of the 8th Thermal Conductivity Conference, Purdue University, 1968, pp. 587-601.

20. R. Pascard. "Properties of Carbides and Carbonitrides," AIME Symposium on Plutonium Fuels Technology, Phoenix, Arizona. October 1967. pp. 345-368.

21. J. B. Moser and O. L. Kruger, "Thermal Diffusivity of Actinide Compounds, " Proceedings of the 7:is Thermai Conductivity Conierence. Gaithersberg. Maryland, November 1967, pp. 461-467.

22. D. Stahl and A. Strasser. "Properties of Solld Solution Uranium-Plutonium Cerbides, " in Carbides in Nuclear Energy. L. E. Russell. et al.. Eds. . MacMllian and Co., Ltd., London. 1964) pp. $373-391$. 
23. G. J. Janz, Molten Salts Handbook (Academlc Press, New York, 1967), pp. 46-47.

24. E. K. Storms, The Refractory Carbides (Academic Press, New York, 1967), Pp. 195 and 222.

25. "Quariorly Status Report on the Advanced Plutonium Fuela Program, April 1 through June 30, 1970, and Fourth Annual Report, FY 1970, " Los Alamos Scientific Laboratory report LA-4494-MS, p. 26 (1970).

26. G. J. Janz, Molten Salts Handbook (Academic Pregs, New York, 1967), pp. 135-192.

27. Y. S. Touloukdan, R. W. Powell, Y. C. Ho, and P. G. Klemens, Thermophysical Properties of Matter, Vol. 1, Thermal Conductlvity, Metallic Elements and Alloys (Plenum Publiahing Corporation, Now York, 1970).

28. Y. S. Toulouktan and E. H. Buyco, Thermophysical Properties of Matter, Vril. 4, Spedific Heat, Metallic Elements and Allcys (Plenum Publlshing Corporation, New York, 1970).

29. J. G. Conner and S. W. Porerbka, "A Compendium of Properties and Characteristics for Selected LMFBR Cladding Materials," Battelle Memorial Institute report BNII-1900 (May 1968).

30. Y. S. Touloukian and D. P. DeWhtt, Thermophyslcal Properties of Matter, Vol. 7, Thermal Radiative Properties, Metalle Elements and Alloys (Plonum Fublishlng Corporation, New York, 1970\}.
31. "Aerospace Structural Materlals Hendbook, " Ait Force Materials Laboratory report AFML-TR68-1 15, Wright Patterson Air Force Base, Ohlo (1971).

32 R. E. Bolz and G. L. Tuve, Eds., Handbook of Tables for Applied Englneering Solence (The Chomleal Rubber Company, Cleveind, 1970), pp. 96-97.

33. J. B. Conway and A. C. Iosekamp, "ThermalEquansion Characteristics of Several Refractory Metals to $2500^{\circ} \mathrm{C}$," Trans. Met. Soc. ADME, 236, 702-709 (1966).

34. G. H. Golden and J. V. Tokar, "Thermophysical Properties of Sodlum, "Argonne National Laboratory report ANL-7323 (Auguet 1967).

35. Y. S. Touloukien, P. E. Llley, and S. C. Saxena, Thermoplurglcal Properties of Matter, Vol. 3. Thermal Concuctivity, Non-Metallio Liquids, and Geses (Plenum Publishing Corporation, Ne'w York 1970).

30. Y. S. Touloukjan and T. Makita, Thermophysical Propertles of Matter, Vol. 6, Speclfic Heat, NonMotallie Liquids, and Cases (Plenum Publishing Corporation, New York, 1970). 